\title{
ARTICLE
}

Cite this: DOI: $10.1039 /$ xoxxooooox

Received ooth January 2012,

Accepted ooth January 2012

DOI: 10.1039/xoxxooooox

www.rsc.org/

\section{Significance of surface charge and shell material of Superparamagnetic Iron Oxide Nanoparticles (SPIONs) based core/shell nanoparticles on the composition of the protein corona}

\author{
Usawadee Sakulkhu a , Morteza Mahmoudi ${ }^{\text {b,c }}$, Lionel Maurizi a , Geraldine \\ Coullerez ${ }^{\text {a }}$, Margarethe Hofmann-Amtenbrink ${ }^{\mathrm{d}}$, Farhad Rezaee ${ }^{\mathrm{e}}$, and Heinrich \\ Hofmann $^{\text {a* }}$
}

\begin{abstract}
As nanoparticles (NPs) are increasingly used in many applications their safety and efficient applications in Nanomedicine have been concerned. Protein coronas on nanomaterials' surfaces can influence how the cell "recognizes" nanoparticles, the in vitro and in vivo NPs' behaviors.. SuperParamagnetic Iron Oxide Nanoparticles (SPIONs) is one of the most prominent agents because of their superparamagnetic properties, useful for separation applications. To mimic surface properties of different type NPs, core-shell SPION library was prepared by coating with different surfaces: polyvinyl alcohol polymer (PVA) (positive, neutral and negative), $\mathrm{SiO}_{2}$ (positive and negative), titanium dioxide and metal gold.. The different surface SPION were incubated at a fixed serum:nanoparticle surface ratio, magnetically trapped and washed. The tightly bound proteins were quantified and identified. The surface charge has a great impact on protein adsorption, especially on PVA and silica surfaces where proteins preferred binding the neutral and positively charged. The importance of surface material on protein adsorption was also revealed by the preferential binding on $\mathrm{TiO} 2$ and gold coated SPION, even negatively charged. There is no correlation between the protein net charge and the nanoparticle surface charge on protein binding, nor direct correlation between the serum proteins' concentration and the proteins detected in the coronas.
\end{abstract}

\section{Introduction}

SuperParamagnetic Iron Oxide Nanoparticle (SPION) has promising biomedical applications. The biomedical applications of coated SPION can be divided into 3 major groups: separation (e.g. cellular proteomics, cell sorting ${ }^{1}$, purification), therapy (e.g. hyperthermia ${ }^{2}$, drug delivery $^{3}$ ) and diagnosis (e.g. Magnetic Resonance Imaging: MRI $^{4,5}$, cell tracking $\left.{ }^{6-9}\right)$. Coating of SPION with variety of polymers has been approved for some clinical applications. The nanoparticles (NPs) coated with dextran i.e. ferucarbotran have been used as contrast agents in MRI ${ }^{10}$. Coating with polyelectrolyte PEI-PEG-chitosan copolymer was used for gene delivery ${ }^{11}$. Moreover, coating of NPs with other hydrophilic polymers such as polyethylene glycol (PEG), polyvinyl alcohol (PVA) or poly (acrylic acid) has been used for imaging and drug delivery ${ }^{12}$. In addition to polymeric coating, inorganic coatings of SPION with silica or gold have interested researchers and industry since many years for further surface derivatization of NPs and because of their influences on colloidal stability and the biological behaviour of
SPION in biomedical applications ${ }^{13,14}$. SPION are also of interest in the discovery of biomarker proteins for example in blood plasma, serum or urine, which are easily accessible to acquire secreting or releasing proteins from cells and various interconnecting tissues. These proteins may indicate a disease status if detected and by this serve as biomarkers. On the other hand, as the most of the nanoparticle formulation, SPION must also be safe for any biomedical applications. The safety of the nanoparticles (NPs) using in biomedical application mainly relates to NP stability, biodistribution and toxicity ${ }^{15}$. Without coating, naked SPION are not stable and become aggregate at physiological $\mathrm{pH}$. In order to overcome this shortcoming, various materials as coating are employed at the surface of SPION. Coating of SPION does not only improve the colloidal stability but also increase the opportunity to functionalize molecules (e.g. fluorescent dyes, polymers, radiotracers, drugs or targeting biomolecules such as antibodies) onto SPION surface.

Once the NPs are exposed to biological environments, biomolecule adsorption immediately occurs. If NPs were 
injected into the body, blood proteins are the biomolecules that has the highest chance to get in contact with the nanoparticles ${ }^{16}$. Protein adsorption forms protein corona on nanoparticles. Protein adsorption can be categorized by their physiological location into 2 groups: (i) the extracellular and (ii) the inter/intracellular (effects between cell-cell junctions and within cells) protein adsorption. Extracellular protein adsorption depends on nanoparticle characteristic (e.g. size, shape, surface area, surface charge, roughness and porosity, functional groups, ligands, crystallinity and hydrophobicity-hydrophilicity) and suspending media ${ }^{17}$. The largest influence factors on the adsorption are emanated from acids and bases, salts and multivalent ions, natural or synthetic organic matters (e.g. proteins, lipids, surfactants, polymers, and polyelectrolytes). All these factors determine nanoparticle stability and behavior in biological fluids ${ }^{18}$. The extracellular protein adsorption will consequently influence on the protein adsorption in the inter/intracellular level.

It is one of the major driving forces for the choice of a nanoparticle destination for theranostic applications, which will further affect cells, tissues and finally a body system. Common proteins like albumin, fibrinogen, IgG, complement C3 and apolipoprotein A-I, apolipoprotein $\mathrm{E}^{19,20,21,22}$ bind to varies semi-solid nanoparticles, for instance liposomes, and solid nanoparticles like of polymeric or inorganic nature, such as iron oxide, silica, titanium oxide, etc. Some of them also covered by polymer coatings or carbon based nanoparticles like nanotubes. All of these mentioned proteins are highly abundant in blood plasma, whereby already $99 \%$ of the protein mass in human blood plasma is covered by 22 of the most abundant proteins ${ }^{23,24,25}$. It is now the challenge of biomarker development to find the specific but very rare protein disease markers (tissue-derived proteins) within the $1 \%$ of the remaining proteins of the blood plasma, already diluted on their way to the blood stream.

The constitution of protein corona depends on two main parameters: i) composition of the biological milieu and ii) the surface property of SPION. Further cellular/tissue responses are due to the composition of corona. The uptake of nanoparticles are determined by particles-protein corona-membrane interactions, receptor-ligand binding interactions, membrane wrapping, biomolecule interaction, conformational change in biomolecules ${ }^{17}$. It is reported that the protein coating reduces the targeting capability of surface engineered NPs by screening the active sites of the targeting ligands ${ }^{26}$. It was revealed that the presence of the corona (protein layer) inhibits the formation of $A \beta$ fibrils (which is the main cause of Alzheimer's diseases) ${ }^{27}$ for all of the tested nanomaterials (e.g. carbon nanotubes and silica nanoparticles). All of these factors finally determine either activation or damage of physiological responses such as oxidant injury, mitochondrial and lysosomal damage $^{28}$. If the cellular damage is severe, it might cause an adverse effect on the body system level. This is the reason why the synthesis of and surface modification of NP to get rid or to minimize the negative effects on the cell behavior as well as to reduce the clearance of NPs in vivo become one of the most interesting topics for medical applications. Recently Giri et al ${ }^{29}$ has presented a detailed study of the composition of the protein corona of gold nanoparticles at incubation times between 15 and $24 \mathrm{~h}$. They showed that proteins adsorbed in the first 15 min has a significant higher isoelectric point than the mean theoretical isoelectric point of all proteins present in the incubation media. Regarding the influence of the protein secondary structure on adsorption, Fleischer et al. ${ }^{30}$ showed that BSA adsorbed on negatively (carbocylate modified and positively charged (amine) polystyrene particle. Circular dichroism spectra shows no changes for BSA on negatively charged particles whereas a significant change was observed for BSA adsorbed at positively charged NPs. As a consequence, the amount of adsorbed proteins and interaction with receptors at the cell surface is different for negatively and positively charged particles.

The research on interaction between plasma proteins and nanoparticle has been increasingly reported. Many ex-situ methods have been applied to investigate protein corona on NPs, all showing advantages and limitations such as centrifugation, gel filtration, or membrane-based microfiltration $^{31,32}$. Centrifugation assays has been reported as an efficient way to retrieve enough protein for safe identification of protein adsorption patterns, if conducted with care and accompanied with other methods to avoid false positive results due to insufficient washing of high abundance proteins. Moreover, sedimentation of large proteins, protein aggregates, and co-precipitation may further complicate the picture. SPION containing nanoparticles offer therefore the possibility to be rapidly isolated from bio fluids by magnetic separation technique, preventing contamination or degradation during the purification process and with significant improvement in recovery yield of proteins and particles ${ }^{22}$. A magnetic separation technique with high gradient magnetic separation column offers in particular the greatest advantage of simplicity of operation, possibility to optimize separation efficiency upon flow rate under reduced shear forces and controlled elution conditions ${ }^{33,34}$.

Nonspecific protein adsorption on the surface of nanoparticles and formation of protein corona are widely seen as negative side effects, screening the targeting ability of functional nanoparticles to specific receptors on cells in biological fluids in vitro or in vivo ${ }^{35}$. On the other hand the formation of biomolecular corona is also relevant to create bionanoconjugates that can stabilize the nanoparticle ${ }^{36}$, promote interactions with biological systems ${ }^{37,38}$ or a way to capture therapeutic biomarkers through engineered nanoparticle-protein interface ${ }^{39}$. The advantages and disadvantages of the proteinnanoparticle interaction with the correspondent in vitro or in vivo biological impact are strongly dependent on the type and amounts of corona protein content. In the current study, SPION coated with PVA polymer varying surface charge from highly positive (amine modified), positive (mixture of amine modified PVA copolymer and unmodified plain PVA), neutral (unmodified plain PVA), negative (carboxylic acid modified PVA), with inorganic coatings such as silica shell using 
tetraethyl orthosilicate (TEOS) and 3aminopropyltriethoxysilane (APTES), with $\mathrm{TiO}_{2}$ and with gold layer were synthesized (Figure 1). The different surface property NPs were expected to influence the formation of the protein corona in fetal bovine serum (FBS) commonly used in in vitro cell culture. As it is essential to identify the protein corona that may ultimately play a biological role, a high resolution LC-MS/MS analysis was applied to allow a precise quantification of all adsorbed proteins. The aim of this study was to determine whether the different surface coatings influence the preferentially binding of certain serum proteins (low and high abundant proteins) and to determine the relative abundance of the adsorbed proteins.

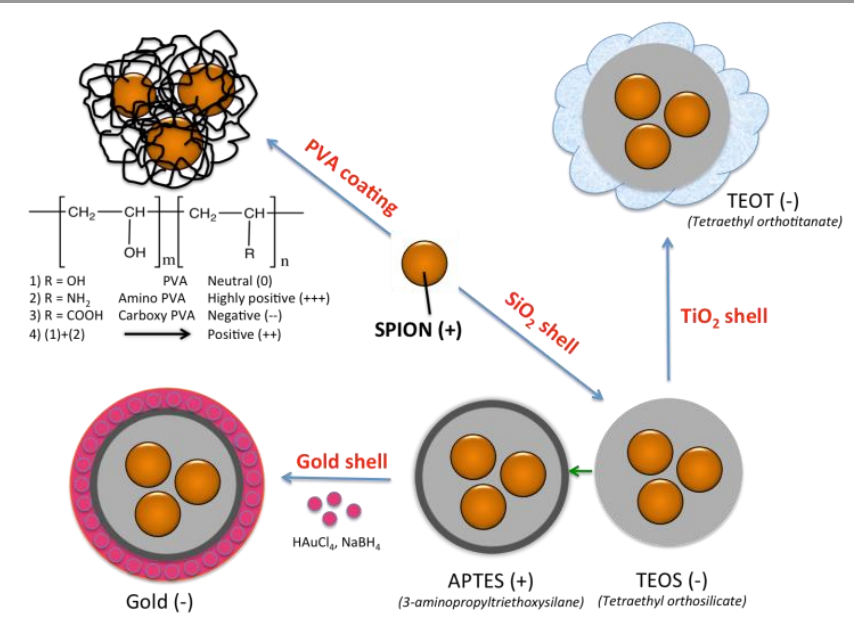

Figure 1. Outlining of the various employed coating at the surface of SPION.

\section{Results and discussion}

COATED SPION CHARACTERIZATION (SIZES AND ZETA POTENTIALS). The 9 different core/shell iron oxide nanoparticles were produced to investigate the FBS protein adsorption. The characteristics of the produced nanoparticles are shown in Figure 2 and Table 1. The particle diameter size of naked SPION, inorganic and metallic core-shell NPs were measured by Transmission Electron Microscope (TEM), while hydrodynamic diameter of PVA coated NPs and the zeta potential of all NPs were measured in deionized water by Photo Correlation Spectroscopy (PCS). The nanoparticles used in this study were all less than $150 \mathrm{~nm}$ in diameter. The variation of the size of highly positively charged PVA(NH2) -SPION, positively charged $\mathrm{PVA}(\mathrm{NH} 2) /(\mathrm{OH})-\mathrm{SPION}$, neutral PVA(OH)-SPION and negatively charged PVA(COOH)SPION (71, 47, 113, and $79 \mathrm{~nm}$ respectively), suggesting the coverage of the polymer on NPs surface and different hydration degree of the PVA layer that should be considered in protein adsorption formation. The mean diameter size of $\mathrm{SiO}_{2}, \mathrm{TiO}_{2}$ and Au coated SPION that measured by TEM were varied from 50 and $144 \mathrm{~nm}$ (with the iron oxide core $\sim 8 \mathrm{~nm}$ ).

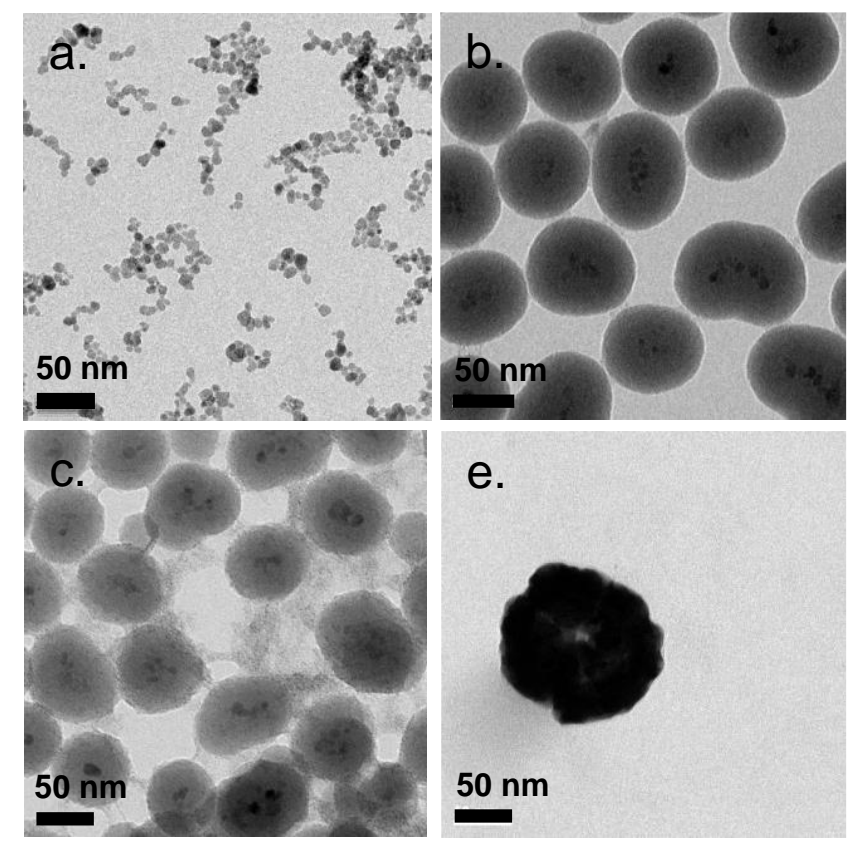

Figure 2. Transmission Electron Microscopy (TEM) images of naked SPION (a), SiO2-SPION (b), TiO2-SPION (c) and gold-SPION (d).

Coating of an initial naked SPION (Zeta potential: $\sim 27 \mathrm{mV}$ ) with different materials lead to NPs with different surface charges. SPION coated with PVA containing amino and carboxylic acid groups showed positive and negative charges of $\sim 13$ and $\sim-15 \mathrm{mV}$, respectively. SPION coated with a plain PVA (-OH) showed a slightly positive charge of $6 \mathrm{mV}$ and used as a representative of a neutral particle. The increasing size and the different surface charges of these 3 particles suggested a successful coating of polymer onto a SPION surface when compared to naked SPION core. Inorganic $\mathrm{SiO}_{2}$ shell nanoparticle showed negative and positive charges after coating with TEOS and APTES respectively. The particles were spherical shape with multi core SPION (bead form). $\mathrm{TiO}_{2}$ and gold coated SPION showed strong negatively charged surface with zeta potential of -24.9 and $-48 \mathrm{mV}$, respectively, confirming a successful coating of these two materials onto SPION as reported in previous works ${ }^{40,41}$. In addition, the presence of inorganic shell was confirmed by TEM images (Figure 2). SPION core represented by dark $8 \mathrm{~nm}$ nanoparticles (a) inside lighter shell of silica $\mathrm{SiO}_{2}$ (b.) and $\mathrm{TiO}_{2}$ (c), while gold shell was confirmed by a larger nanoparticle size with high electron dense of gold shell (d). 
Table 1. Summary of size and zeta potential of polymeric, inorganic and metallic coated SPION measured in DI water

\begin{tabular}{|c|c|c|c|c|}
\hline Sample & $\begin{array}{c}\text { Hydrodynamic } \\
\text { mean diameter } \\
\text { (by number) } \\
(\mathrm{nm})\end{array}$ & $\begin{array}{l}\text { TEM } \\
(\mathrm{nm})\end{array}$ & $\begin{array}{c}\text { Zeta } \\
\text { potential } \\
(\mathrm{mV})\end{array}$ & $\begin{array}{c}\text { Point of } \\
\text { zero } \\
\text { charge } \\
(\text { pzc) }\end{array}$ \\
\hline Naked SPION & $28 \pm 3$ & $7.7 \pm 2.2$ & $27.5 \pm 3.0$ & 7.0 \\
\hline $\begin{array}{c}\text { PVA }_{(\mathrm{NH} 2)}- \\
\text { SPION }(++++) \\
\end{array}$ & $71.8 \pm 0.143$ & - & $34.6 \pm 2.1$ & 9.0 \\
\hline $\begin{array}{l}\text { PVA }_{(\mathrm{NH} 2) /(\mathrm{OH})^{-}} \\
\text {SPION }(+++) \\
\end{array}$ & $46.8 \pm 0.088$ & - & $13.6 \pm 1.3$ & 8 \\
\hline $\begin{array}{c}\mathrm{PVA}_{(\mathrm{OH})}-\mathrm{SPION} \\
(0)\end{array}$ & $112.7 \pm 0.155$ & - & $5.6 \pm 0.9$ & 7 \\
\hline $\begin{array}{l}\text { PVA }_{(\mathrm{COOH})^{-}} \\
\text {SPION (-) }\end{array}$ & $78.5 \pm 0.006$ & - & $-15.5 \pm 1.0$ & 5 \\
\hline $\begin{array}{l}\mathrm{SiO}_{2 \text { (TEOS)- }} \\
\text { SPION } \\
\end{array}$ & - & $\begin{array}{c}102.1 \pm \\
25.2 \\
\end{array}$ & $-36.6 \pm 1.4$ & 3 \\
\hline $\begin{array}{l}\mathrm{SiO}_{2 \text { (APTES) }} \\
\text { SPION }\end{array}$ & - & $\begin{array}{c}100.7 \pm \\
28.2\end{array}$ & $36.8 \pm 1.9$ & 9 \\
\hline $\mathrm{TiO}_{2}$-SPION & - & $\begin{array}{c}102.1 \pm \\
25.2 \\
\end{array}$ & $-24.9 \pm 0.5$ & 4 \\
\hline Gold-SPION & - & $\begin{array}{c}143.9 \pm \\
18.4 \\
\end{array}$ & $-48.2 \pm 1.6$ & 6 \\
\hline
\end{tabular}

NANOPARTICLE-PROTEIN ADSORPTION. Serum is a complex fluid that contains for human about 3700 different proteins with concentrations up to $70 \mathrm{mg} / \mathrm{ml}$; in which the most abundant proteins such as albumin, immunoglobulin $\mathrm{G}$ (IgG), $\alpha_{2}$ macroglobulin represent $97 \%$ of the total protein content whereas the remaining $3 \%$ is a mixture including low abundant proteins. Identification of all the proteins is therefore a challenging task where proteomic techniques, e.g. electrophoretic methods, chromatography or mass spectrometry can provide qualitative and quantitative analysis of protein patterns and are enabling the detection of potentially relevant biomarker in very low concentration in protein corona when combined with nanomaterials $\left(<\mathrm{ng} / \mathrm{cm}^{2}\right)^{42,43,44}$. Based on the available proteomic information of fetal bovine serum (FBS) reported by Zheng et $a l .{ }^{45}$, the table of abundant proteins was adapted (Table 2). Fetal bovine serum proteins were therefore categorized, as a percentage relative concentration of proteins, into 3 groups: high $(\geq 6 \%)$, medium $(\geq 3 \%)$ and low $(\leq 3 \%)$. Table 3, Table 4 and Table 5 showed the list of proteins adsorbed on the polymer, inorganic and metallic coated SPION with increased specificity for nanoparticle surface, i.e. protein common to several particles $>2$ to 2 and only 1 surface type, respectively. A color code was used to show the adsorbed protein upon their relative abundance in FBS, e.g. in red (high), green (medium) and yellow (low abundance).
EFFECT OF NANOPARTICLE SURFACE CHARGE ON PROTEIN CORONA. As depicted in Table 3, based on the theoretical protein isoelectric point from http://web.expasy.org/compute_pi/, no clear correlation between protein isoelectric point (IEP) and protein adsorption on nanoparticles with different surface charge could be observed. For instance, alpha-2-HS-glycoprotein (IEP 5.26)

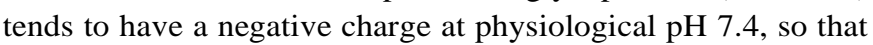
according to electrostatic binding the protein should preferentially adsorb onto the positively charged nanoparticles. However, alpha-2-HS glycoprotein bound on all kinds of nanoparticles irrespective of their surface charge. Electrostatic effect alone, between protein and NPs of opposite surface charge, is therefore not the only driving force that can explain the protein adsorption. It is well known that proteins have an inhomogeneous distribution of charges at their surfaces. Therefore, even the overall net charge of the protein is negative; existing positive charge domains may allow an electrostatic interaction with the particle surface. In addition, the formation of the protein corona will involve simultaneously a combination of protein-particle and protein-protein interactions. Adsorption models of corona consisting of sequential attachment and multiple layers of proteins are also proposed, that consist of primary binding proteins to the NP surface followed by secondary binders mediated by proteinprotein interactions ${ }^{46}$, e.g. opposite charged anionic to cationic proteins, or by specific recognition of molecular cues on primary protein layer. Protein conformational change and denaturation could additionally occur after adsorption onto a solid interface driven by favorable protein-surface interaction and an entropy gain due to loss of ordered secondary structure. Rankl M. et al. (2006) has proven that immunoglobulin G (IgG) undergoes conformational changes during non-specific binding once it is exposed to different surface models ${ }^{47}$. Particle size, i.e. surface curvature can also have a significant effect on the protein conformational change $\mathrm{e}^{48,49}$ and ultimately on protein corona with variability upon the surface chemistry and surface charge. Size dependent protein adsorption was for example shown on PS nanoparticles of two different sizes $(50 \mathrm{~nm}, 200$ $\mathrm{nm}$ ) with more pronounced trend in amine and carboxylic acid containing particles compared to neutral surfaces ${ }^{50}$. Moreover, protein adsorption on NP surface also depends on the time of protein-particle incubation. The adsorption/desorption process could happen via either reversible or irreversible protein conformational change during incubation ${ }^{51}$. 


\section{ARTICLE}

Table 2. Level of protein abundance in fetal bovine serum

\begin{tabular}{|c|c|c|}
\hline Level of Abundance & Protein & $\%$ Relative concentration of protein \\
\hline \multirow{5}{*}{ High $(>6 \%)$} & serum albumin & 18.7 \\
\hline & alpha-1-antiproteinase & 7.9 \\
\hline & plasminogen & 6.4 \\
\hline & $\begin{array}{c}\text { cone cGMP-specific 3',5'-cyclic phosphodiesterase alpha- } \\
\text { subunit }\end{array}$ & 6.1 \\
\hline & lactoperoxidase & 6.1 \\
\hline \multirow{10}{*}{$\begin{array}{c}\text { Medium } \\
(3 \%<\mathrm{X} \leq 6 \%)\end{array}$} & NADH-ubiquinone oxidoreductase 75 & 5.2 \\
\hline & alpha-2-HS-glycoprotein & 5.2 \\
\hline & kininogen, LMW II & 4.7 \\
\hline & hemiferrin & 4.7 \\
\hline & integrin beta- 1 & 4.7 \\
\hline & prothrombin & 4.4 \\
\hline & apolipoprotein A-I & 3.8 \\
\hline & antithrombin-III & 3.8 \\
\hline & beta-2-glycoprotein I & 3.5 \\
\hline & alpha-2-antiplasmin & 3.2 \\
\hline \multirow{5}{*}{ Low $(\leq 3 \%)$} & $\begin{array}{l}\text { alpha-1-1-microglobulin and inter alpha-trypsin inhibitor light } \\
\text { chain }\end{array}$ & 2.9 \\
\hline & hemoglobin beta fetal chain & 2.9 \\
\hline & alpha 1 antichymotrypsin & 2.3 \\
\hline & apolipoprotein A-II & 1.7 \\
\hline & hemoglobin $\mathrm{R}$ chain & 1.7 \\
\hline
\end{tabular}

The protein corona appears to follow a general structure with a few proteins adsorbed at high abundance and many more at low abundance although the composition in the corona do not necessarily correlate with the relative abundances of the proteins in the biological milieu. The proteins compete for the surface through a dynamic process ("Vroman Effect") based on proteins abundance, affinities, and incubation time with nanopartcicles. Upon to exposure to the serum the most abundant and smaller molecular weight proteins cover first the NPs, e.g. albumin, IgG, or fibrinogen in plasma and are replaced by proteins with slower adsorption rates but higher affinity, e.g. apolipoproteins although the phenomenon is still debated for nanomaterials ${ }^{52}$. Protein adsorption is a dynamic system. The adsorption/desorption process could happen via either reversible or irreversible protein conformational change during incubation ${ }^{51}$ and the protein corona therefore hypothesized to consist of long-lived hard shell of proteins assumed irreversibly bound. The corona is not immediately established but change over time until equilibrium is reached ${ }^{53,54}$. Temporal studies showed that equilibrium takes place in few minutes for nanoparticle incubated with full protein serum ${ }^{55}$.

Based on competitive binding between serum proteins, highly abundant proteins generally were expected to bind on the NPs with higher probability than low abundant proteins and to all nanoparticle surfaces. Surprisingly, from the 5 listed high abundant proteins, 2 proteins were not detected on any particle surfaces, i.e. cone cGMP-specific 3',5'-cyclic phosphodiesterase alpha-subunit and lactoperoxidase. The highly abundant plasminogen binds to only 4 of the 9 investigated NPs. The surface specific binding of highly abundant protein reveals that the need of a specific surface character for protein adsorption is not ignorable. Only serum albumin and alpha-1-antiproteinase were found on 8 of the 9 different particles, both did not adsorb on negatively charged silica coated SPION. 
It is obvious that proteins preferred to bind on positively charged NPs rather than on negatively charged NPs. Positively charged PVA coated and positively charged $\mathrm{SiO}_{2 \text { (APTES) coated }}$ NPs showed similar pattern of adsorbed proteins indicating an influence of surface charge on protein adsorption. However, the presence of alpha-2-antiplasmin and plasminogen on highly positively charged PVA coated SPION $\left(-\mathrm{NH}_{2}\right)$, but not on

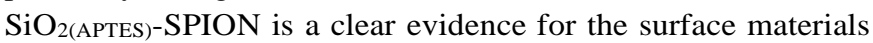
effect. Previous studies showed that the main proteins that associated with large particles (and hydrophobic surfaces) were albumin, IgG and antibodies, complement proteins, and apolipoptroteins ${ }^{56,22}$. Of note, these proteins belong to high abundant plasma proteins (some of complement factors) with apolipoproteins as hydrophobic proteins. Surprisingly, none of the high abundant proteins, e.g. serum albumin, alpha-1antiproteinase, plasminogen bound on negatively charged silica

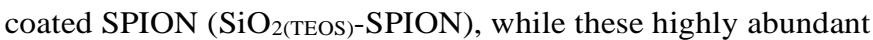
proteins (except plasminogen) bound to all PVA coated nanoparticles. One of the reasons could be that albumin (IEP 4.7-4.8) is negatively charged at physiological pH. Although $\mathrm{TiO}_{2}$ and gold coated SPION had negative charges, more than 50 proteins bound on these particles. This indicates the surface materials play an important role in protein adsorption. There are some proteins bound specifically to certain nanoparticle (Table 5). This knowledge would be useful for further experimental design for a biomarker study.

EFFECT OF DIFFERENT SURFACE CHARGE OF POLYMER COATING ON PROTEIN ADSORPTION. PVA has been widely used in biomedicine for biomedical devices and pharmaceutical applications because of suitable properties e.g. hydrophilic, biocompatible, nontoxic, non carcinogenic, non immunogenic, inertness in body fluids and conferring biopassive properties to surfaces. Although those surfaces show reduced protein adsorption, a large number of proteins can still adsorb from full serum and vary with the polymer physico-chemical properties and coating ${ }^{57,58}$. The total number of proteins that bind to PVASPION decreased upon the PVA coating on SPION in the order $\mathrm{PVA}-\mathrm{NH} 2>\mathrm{PVA}-\mathrm{OH}>\mathrm{PVA}\left(\mathrm{NH}_{2} / \mathrm{OH}\right)>\mathrm{PVA}-\mathrm{COOH}$. Neutral to highly positively charged NPs bound a wide range of proteins and showed similar protein binding patterns whereas negatively charged PVA coated SPION bound little number of proteins (Table 3). Only 5 protein types bound on the negatively charged PVA coated SPION while 24, 55, 31 and 34 proteins were found on naked SPION, highly positive, positive and neutral PVA coated SPION, respectively. Serum albumin, Alpha-1-antiproteinase, Alpha-2-HS-glycoprotein were highly abundant proteins which bound to naked SPION and to all PVA coated SPION. In addition, complement C3, a low abundant protein also binds on all types of PVA surfaces. Serum albumin is a highly abundant protein which plays a role on opsonization and increasing nanoparticle half-life in blood ${ }^{59}$. Alpha-1antiproteinase is an inhibitor of serine proteases. Its primary target is elastase, but it also has a moderate affinity for plasmin and thrombin and inhibits trypsin, chymotrypsin and plasminogen activators ${ }^{60}$. Alpha2-HS glycoprotein is more abundant in fetal than in adult blood. It is involved in several functions, such as endocytosis, brain development and the formation of bone tissue ${ }^{61}$. Hirsch et al. ${ }^{34}$ also found these three abundant proteins on positively, neutral and negatively charged PVA coated SPION. Deviation in the total amount of proteins found on all investigated PVA-SPION surface described in Hirsch et al. work could be due to different protein content fluids performed at lower concentration of serum $(10 \% \mathrm{v} / \mathrm{v}$ in PBS) versus full FBS serum in our study and sample preparation for MS analysis.

Protein corona on polymer coated particles did not reflect the relative abundance of proteins in the serum. Albumin the most abundant protein in serum is well detected on all the surfaces but the protein corona composition revealed also enrichment in apolipoprotein versus albumin in all the PVA coated SPION. Albumin can indeed be displaced by other proteins in serum and result in different protein corona, e.g. around positive and negative charged particles $^{34}$. Apolipoproteins A-I has furthermore been detected in the corona of many other nanoparticle silica, lipid to polymeric nanoparticles, e.g. PS and polyNIPAM copolymers ${ }^{20,31,50}$ suggesting that lipid coating is a general feature of nanoparticles in physiological conditions ${ }^{62}$. Apolipoprotein might be affected in different ways by the surface characters of the particles and undergo in particular conformational changes on surfaces of different charges ${ }^{63}$ that can explain the clear difference of protein composition between negatively charged PVA-SPION and other PVA-SPION. Multiple studies have however also reported that surface hydrophobicity played an important role in protein adsorption to nanoparticles e.g. mediated by interaction with lipid binding domain. Difference in relative abundance in apolipoprotein might reflect the relative abundance of functional groups amino, alcohol, and carboxylic acid and relative hydrophobicity/hydrophilicity of the different polymer layers. The central role of lipoproteins was also shown in fouling of proteins plasma on various polymeric biomaterials on flat surfaces $^{64}$.

The absence of kininogen on positively charged nanoparticles was already observed for amine-modified silica nanoparticle in the work from Lundqvist et $\mathrm{al}^{50}$. Interestingly, kininogen (high molecular weight) has been reported as surface binding protein to iron oxide through histidine-rich sequences and is a possible marker of incompletely masked iron oxide core as shown with loose dextran coating of ferumoxides ${ }^{46}$. 
Table 3. List of protein adsorption on polymeric coated, inorganic and metallic coated SPION (protein bound to $>2$ nanoparticles). The color indicates the relative abundance of the protein in the serum (red: high, green: medium, yellow: low and white: very low).

\begin{tabular}{|c|c|c|c|c|c|c|c|c|c|c|c|c|c|}
\hline \multirow[b]{3}{*}{ Protein } & \multirow[b]{3}{*}{ Accession } & \multirow{3}{*}{$\begin{array}{c}\text { Protein } \\
\text { molecular } \\
\text { weight (Da) }\end{array}$} & \multirow{3}{*}{$\begin{array}{l}\text { Theoritical } \\
\text { Protein IEP }\end{array}$} & \multirow{2}{*}{$\begin{array}{c}\text { Core } \\
\text { Positive } \\
\end{array}$} & \multicolumn{4}{|c|}{ organic shell (PVA) } & \multicolumn{3}{|c|}{ Inorganic shell } & \multirow{2}{*}{\begin{tabular}{c|} 
Metalic shell \\
Negative
\end{tabular}} & \multirow[b]{2}{*}{$\begin{array}{l}\text { Number of } \\
\text { NP type }\end{array}$} \\
\hline & & & & & $\begin{array}{c}\text { Highly } \\
\text { positive }\end{array}$ & Positive & Neutral & Negative & Positive & Negative & Negative & & \\
\hline & & & & SPION & $-\mathrm{NH2}$ & $-\mathrm{NH} 2 / \mathrm{OH}$ & $\mathrm{OH}$ & $\mathrm{COOH}$ & $\mathrm{SiO}_{2}$ (APTES) & $\mathrm{SiO}_{2}$ (TEOS) & $\mathrm{TiO}_{2}$ & $\mathrm{Au}$ & \\
\hline \begin{tabular}{|l|} 
Alpha-2-HS-glycoprotein \\
\end{tabular} & FETUA & 38419 & 5.26 & & & & & & & & & & 9 \\
\hline Complement C3 & $\mathrm{CO} 3$ & 187252 & 6.41 & & & & & & & & & & 9 \\
\hline Serum albumin & ALBU & 69294 & 5.82 & & & & & & & & & & 8 \\
\hline \begin{tabular}{|l|} 
Alpha-1-antiproteinase \\
\end{tabular} & A1AT & 46104 & 6.05 & & & & & & & & & & 8 \\
\hline \begin{tabular}{|l|} 
Apolipoprotein A-I \\
\end{tabular} & APOA1 & 30276 & 5.71 & & & & & & & & & & 8 \\
\hline Actin, cytoplasmic 2 & ACTG & 41793 & 5.31 & & & & & & & & & & 8 \\
\hline Actin, cytoplasmic 1 & ACTB & 41737 & 5.29 & & & & & & & & & & 8 \\
\hline \begin{tabular}{|l|} 
Apolipoprotein E \\
\end{tabular} & APOE & 35980 & 5.55 & & & & & & & & & & 8 \\
\hline \begin{tabular}{|l|} 
Alpha-2-macroglobulin \\
\end{tabular} & A2MG & 167575 & 5.71 & & & & & & & & & & 7 \\
\hline Complement factor B & CFAB & 85366 & 7.87 & & & & & & & & & & 7 \\
\hline \begin{tabular}{|l|} 
Fibrinogen alpha chain \\
\end{tabular} & FIBA & 67012 & 6.73 & & & & & & & & & & 7 \\
\hline Pigment epithelium-derived factor & PEDF & 46229 & 6.57 & & & & & & & & & & 7 \\
\hline Hemoglobin subunit alpha & HBA & 15184 & 8.07 & & & & & & & & & & 7 \\
\hline Prothrombin & THRB & 70506 & 5.97 & & & & & & & & & & 6 \\
\hline Kininogen-2 & KNG2 & 68710 & 6.09 & & & & & & & & & & 6 \\
\hline Alpha-2-antiplasmin & A2AP & 54711 & 5.45 & & & & & & & & & & 6 \\
\hline \begin{tabular}{|l|l|} 
Clusterin \\
\end{tabular} & CLUS & 51114 & 5.73 & & & & & & & & & & 6 \\
\hline Hemoglobin subunit beta & HBB & 15954 & 7.02 & & & & & & & & & & 6 \\
\hline Hemoglobin fetal subunit beta & HBBF & 15859 & 6.51 & & & & & & & & & & 6 \\
\hline Thrombospondin-1 & TSP1 & 129534 & 4.74 & & & & & & & & & & 5 \\
\hline Inter-alpha-trypsin inhibitor heavy chain $\mathrm{H} 4$ & $\mid \mathrm{TIIH} 4$ & 101513 & 6.22 & & & & & & & & & & 5 \\
\hline Inter-alpha-trypsin inhibitor heavy chain $\mathrm{H3}$ & ITIH3 & 99551 & 5.59 & & & & & & & & & & 5 \\
\hline Actin, alpha skeletal muscle & ACTS & 42051 & 5.23 & & & & & & & & & & 5 \\
\hline \begin{tabular}{|l|} 
Actin, alpha cardiac muscle 1 \\
\end{tabular} & ACTC & 42019 & 5.23 & & & & & & & & & & 5 \\
\hline Actin, aortic smooth muscle & ACTA & 42009 & 5.24 & & & & & & & & & & 5 \\
\hline Actin, gamma-enteric smooth muscle & ACTH & 41877 & 5.31 & & & & & & & & & & 5 \\
\hline Plasminogen & PLMN & 91216 & 7.68 & & & & & & & & & & 4 \\
\hline Myosin-10 & MYH10 & 229097 & 5.43 & & & & & & & & & & 4 \\
\hline \begin{tabular}{|l|} 
Gelsolin \\
\end{tabular} & GELS & 80731 & 5.54 & & & & & & & & & & 4 \\
\hline Kininogen-1 & KNG1 & 68890 & 6.14 & & & & & & & & & & 4 \\
\hline Apolipoprotein A-IV & APOA4 & 43018 & 5.3 & & & & & & & & & & 4 \\
\hline Coagulation factor $\mathrm{V}$ & FA5 & 248981 & 5.53 & & & & & & & & & & 3 \\
\hline Heat shock protein HSP 90-alpha & HS90A & 84731 & 4.92 & & & & & & & & & & 3 \\
\hline $78 \mathrm{kDa}$ glucose-regulated protein & GRP78 & 72400 & 5.07 & & & & & & & & & & 3 \\
\hline Tetranectin & TETN & 22144 & 5.47 & & & & & & & & & & 3 \\
\hline \begin{tabular}{|l|l|} 
Apolipoprotein A-II \\
\end{tabular} & APOA2 & 11202 & 7.8 & & & & & & & & & & 3 \\
\hline Heat shock protein HSP 90-beta & HS90B & 83253 & 4.96 & & & & & & & & & & 2 \\
\hline
\end{tabular}


Table 4. List of protein adsorption on polymeric coated, inorganic and metallic coated SPION (protein bound to 2 nanoparticles). The color indicates the relative abundance of the protein in the serum (red: high, green: medium, yellow: low and white: very low).

\begin{tabular}{|c|c|c|c|c|c|c|c|c|c|c|c|c|c|}
\hline \multirow[b]{3}{*}{$\begin{array}{l}\text { Protein } \\
\end{array}$} & \multirow[b]{3}{*}{ Accession } & \multirow{3}{*}{$\begin{array}{c}\text { Protein } \\
\text { molecular } \\
\text { weight (Da) }\end{array}$} & \multirow{3}{*}{$\begin{array}{l}\text { Theoritical } \\
\text { Protein IEP }\end{array}$} & \multirow{3}{*}{$\begin{array}{c}\text { Core } \\
\text { Positive } \\
\text { SPION }\end{array}$} & \multicolumn{4}{|c|}{ organic shell (PVA) } & \multicolumn{3}{|c|}{ Inorganic shell } & \multirow{2}{*}{\begin{tabular}{|c|} 
Metalic shell \\
Negative \\
\end{tabular}} & \multirow{3}{*}{$\begin{array}{l}\text { Number of } \\
\text { NP type }\end{array}$} \\
\hline & & & & & $\begin{array}{l}\text { Highly } \\
\text { positive }\end{array}$ & Positive & Neutral & Negative & Positive & Negative & Negative & & \\
\hline & & & & & $-\mathrm{NH2}$ & $-\mathrm{NH} 2 / \mathrm{OH}$ & $\mathrm{OH}$ & $\mathrm{COOH}$ & $\mathrm{SiO}_{2}$ (APTES) & $\mathrm{SiO}_{2}$ (TEOS) & $\mathrm{TiO}_{2}$ & $\mathrm{Au}$ & \\
\hline \begin{tabular}{|l|} 
Fibrinogen beta chain \\
\end{tabular} & FIBB & 53340 & 8.45 & & & & & & & & & & 2 \\
\hline Complement C4 (Fragments) & $\mathrm{CO} 4$ & 3101551 & 6.68 & & & & & & & & & & 2 \\
\hline \begin{tabular}{|l|} 
Fibronectin \\
\end{tabular} & FINC & 272151 & 5.32 & & & & & & & & & & 2 \\
\hline Complement factor $\mathrm{H}$ & CFAH & 140374 & 6.43 & & & & & & & & & & 2 \\
\hline Collagen alpha-1(I) chain & CO1A1 & 138939 & 5.6 & & & & & & & & & & 2 \\
\hline Complement component C7 & $\mathrm{CO}$ & 93090 & 6.91 & & & & & & & & & & 2 \\
\hline Heat shock cognate $71 \mathrm{kDa}$ protein & HSP7C & 71241 & 5.37 & & & & & & & & & & 2 \\
\hline \begin{tabular}{|l|} 
Plasma kallikrein \\
\end{tabular} & KLKB1 & 70994 & 8.64 & & & & & & & & & & 2 \\
\hline Heat shock $70 \mathrm{kDa}$ protein $1 \mathrm{~A}$ & HS71A & 70259 & 6.57 & & & & & & & & & & 2 \\
\hline \begin{tabular}{|l|} 
Heat shock $70 \mathrm{kDa}$ protein $1 \mathrm{~B}$ \\
\end{tabular} & HS71B & 70229 & 5.67 & & & & & & & & & & 2 \\
\hline \begin{tabular}{|l|} 
Alpha-fetoprotein \\
\end{tabular} & FETA & 68588 & 5.92 & & & & & & & & & & 2 \\
\hline Coagulation factor $\mathrm{X}$ & FA10 & 54510 & 5.35 & & & & & & & & & & 2 \\
\hline Vitamin D-binding protein & VTDB & 53342 & 5.36 & & & & & & & & & & 2 \\
\hline Hemopexin & HEMO & 52209 & 7.9 & & & & & & & & & & 2 \\
\hline Factor XIla inhibitor & F12Al & 51723 & 6.19 & & & & & & & & & & 2 \\
\hline Chromogranin-A & CMGA & 50015 & 4.71 & & & & & & & & & & 2 \\
\hline Tubulin alpha-4A chain & TBA4A & 49924 & 4.93 & & & & & & & & & & 2 \\
\hline Plasma serine protease inhibitor & IPSP & 45297 & 9.4 & & & & & & & & & & 2 \\
\hline \begin{tabular}{|l|} 
L-lactate dehydrogenase B chain \\
\end{tabular} & LDHB & 36724 & 6.02 & & & & & & & & & & 2 \\
\hline Insulin-like growth factor-binding protein 2 & IBP2 & 34015 & 7.13 & & & & & & & & & & 2 \\
\hline Insulin-like growth factor-binding protein 3 & IBP3 & 31570 & 9.03 & & & & & & & & & & 2 \\
\hline Osteopontin-K & OSTK & 30969 & 4.57 & & & & & & & & & & 2 \\
\hline \begin{tabular}{|l|} 
Osteopontin \\
\end{tabular} & OSTP & 30904 & 4.49 & & & & & & & & & & 2 \\
\hline 14-3-3 protein zeta/delta & 14332 & 27745 & 4.73 & & & & & & & & & & 2 \\
\hline Secreted phosphoprotein 24 & SPP24 & 23134 & 8.3 & & & & & & & & & & 2 \\
\hline \begin{tabular}{|l|} 
Transthyretin \\
\end{tabular} & TTHY & 15727 & 5.9 & & & & & & & & & & 2 \\
\hline Beta-2-microglobulin & B2MG & 13677 & 7.79 & & & & & & & & & & 2 \\
\hline Apolipoprotein C-III & APOC3 & 10692 & 5.02 & & & & & & & & & & 2 \\
\hline
\end{tabular}


Table 5. List of protein adsorption on polymeric coated, inorganic and metallic coated SPION (protein bound to 1 nanoparticle). The color indicates the relative abundance of the protein in the serum (red: high, green: medium, yellow: low and white: very low).

\begin{tabular}{|c|c|c|c|c|c|c|c|c|c|c|c|c|c|}
\hline \multirow[b]{3}{*}{ Protein } & \multirow[b]{3}{*}{ Accession } & \multirow{3}{*}{$\begin{array}{c}\text { Protein } \\
\text { molecular } \\
\text { weight (Da) }\end{array}$} & \multirow{3}{*}{$\begin{array}{l}\text { Theoritical } \\
\text { Protein IEP }\end{array}$} & \multirow{2}{*}{$\begin{array}{c}\text { Core } \\
\text { Positive } \\
\end{array}$} & \multicolumn{4}{|c|}{ organic shell (PVA) } & \multicolumn{3}{|c|}{ Inorganic shell } & \multirow{2}{*}{\begin{tabular}{|c|} 
Metalic shell \\
Negative \\
\end{tabular}} & \multirow[b]{2}{*}{$\begin{array}{l}\text { Number of } \\
\text { NP type }\end{array}$} \\
\hline & & & & & $\begin{array}{c}\text { Highly } \\
\text { positive }\end{array}$ & Positive & Neutral & Negative & Positive & Negative & Negative & & \\
\hline & & & & SPION & $-\mathrm{NH2}$ & $-\mathrm{NH} 2 / \mathrm{OH}$ & $\mathrm{OH}$ & $\mathrm{COOH}$ & $\mathrm{SiO}_{2}$ (APTES) & $\mathrm{SiO}_{2}$ (TEOS) & $\mathrm{TiO}_{2}$ & $\mathrm{Au}$ & \\
\hline Serotransferrin & TRFE & 77753 & 6.75 & & & & & & & & & & 1 \\
\hline \begin{tabular}{|l|} 
Antithrombin-III \\
\end{tabular} & ANT3 & 52347 & 7.01 & & & & & & & & & & 1 \\
\hline Beta-2-glycoprotein 1 & $\mathrm{APOH}$ & 38252 & 8.53 & & & & & & & & & & 1 \\
\hline \begin{tabular}{|l|l} 
Versican core protein \\
\end{tabular} & CSPG2 & 369991 & 4.47 & & & & & & & & & & 1 \\
\hline Collagen alpha-2(I) chain & CO1A2 & 129064 & 9.23 & & & & & & & & & & 1 \\
\hline Thrombospondin-4 & TSP4 & 105974 & 4.44 & & & & & & & & & & 1 \\
\hline Inter-alpha-trypsin inhibitor heavy chain H1 & $\mid \mathrm{TIH} 1$ & 101237 & 6.98 & & & & & & & & & & 1 \\
\hline \begin{tabular}{|l|l|} 
Neural cell adhesion molecule 1 \\
\end{tabular} & NCAM1 & 93894 & 4.87 & & & & & & & & & & 1 \\
\hline Cadherin-5 & CADH5 & 87467 & 5.3 & & & & & & & & & & 1 \\
\hline Cartilage oligomeric matrix protein & COMP & 82362 & 4.37 & & & & & & & & & & 1 \\
\hline Heat shock $70 \mathrm{kDa}$ protein 1-like & HS71L & 70389 & 5.89 & & & & & & & & & & 1 \\
\hline Moesin & MOES & 67975 & 5.9 & & & & & & & & & & 1 \\
\hline Glucosidase 2 subunit beta & GLU2B & 60151 & 4.36 & & & & & & & & & & 1 \\
\hline 4-trimethylaminobutyraldehyde dehydrogenase & AL9A1 & 53977 & 5.84 & & & & & & & & & & 1 \\
\hline Carboxypeptidase $\mathrm{N}$ catalytic chain & CBPN & 52669 & 8.75 & & & & & & & & & & 1 \\
\hline \begin{tabular}{|l|l|} 
Integrin-linked protein kinase \\
\end{tabular} & ILK & 51447 & 8.3 & & & & & & & & & & 1 \\
\hline Fibrinogen gamma-B chain & FIBG & 50244 & 5.53 & & & & & & & & & & 1 \\
\hline Tubulin alpha-1B chain & TBA1B & 50152 & 4.94 & & & & & & & & & & 1 \\
\hline Elongation factor 1-alpha 1 & EF1A1 & 50141 & 9.1 & & & & & & & & & & 1 \\
\hline \begin{tabular}{|l|} 
Tubulin beta- 5 chain \\
\end{tabular} & TBB5 & 49671 & 4.78 & & & & & & & & & & 1 \\
\hline Calreticulin & CALR & 48039 & 4.31 & & & & & & & & & & 1 \\
\hline Coagulation factor IX (Fragment) & FA9 & 46785 & 5.47 & & & & & & & & & & 1 \\
\hline Fetuin-B & FETUB & 42663 & 5.59 & & & & & & & & & & 1 \\
\hline Pentraxin-related protein PTX3 & PTX3 & 42021 & 5.08 & & & & & & & & & & 1 \\
\hline $\mathrm{Na}(+) / \mathrm{H}(+)$ exchange regulatory cofactor NHE-RF1 & NHRF1 & 39603 & 5.29 & & & & & & & & & & 1 \\
\hline Protein AMBP & AMBP & 39235 & 7.81 & & & & & & & & & & 1 \\
\hline Lumican & LUM & 38756 & 5.93 & & & & & & & & & & 1 \\
\hline Secreted frizzled-related protein 3 & SFRP3 & 36234 & 8.75 & & & & & & & & & & 1 \\
\hline \begin{tabular}{|l|l|} 
Tropomyosin alpha-3 chain \\
\end{tabular} & TPM3 & 32819 & 4.68 & & & & & & & & & & 1 \\
\hline Tropomyosin alpha- 1 chain & TPM1 & 32695 & 4.69 & & & & & & & & & & 1 \\
\hline 14-3-3 protein beta/alpha & $1433 \mathrm{~B}$ & 28081 & 4.8 & & & & & & & & & & 1 \\
\hline \begin{tabular}{|l|} 
Complement factor D \\
\end{tabular} & CFAD & 27878 & 7.64 & & & & & & & & & & 1 \\
\hline \begin{tabular}{|l} 
Brain acid soluble protein 1 \\
\end{tabular} & BASP1 & 23011 & 4.53 & & & & & & & & & & 1 \\
\hline Transgelin & TAGL & 22599 & 8.87 & & & & & & & & & & 1 \\
\hline \begin{tabular}{|l|} 
Transgelin-2 \\
\end{tabular} & TAGL2 & 22426 & 8.4 & & & & & & & & & & 1 \\
\hline \begin{tabular}{|l|} 
Histone H1.3 \\
\end{tabular} & H13 & 22154 & 10.97 & & & & & & & & & & 1 \\
\hline \begin{tabular}{|l|} 
Flavin reductase (NADPH) \\
\end{tabular} & BLVRB & 22132 & 6.58 & & & & & & & & & & 1 \\
\hline Ras-related protein Rap-1b & RAP1B & 20825 & 5.65 & & & & & & & & & & 1 \\
\hline Beta-lactoglobulin & LACB & 19883 & 4.93 & & & & & & & & & & 1 \\
\hline Profilin-1 & PROF1 & 15057 & 8.46 & & & & & & & & & & 1 \\
\hline Fatty acid-binding protein, liver & FABPL & 14227 & 7.78 & & & & & & & & & & 1 \\
\hline Apolipoprotein C-II & APOC2 & 11061 & 5.67 & & & & & & & & & & 1 \\
\hline Histone H1.2 (Fragment) & H12 & 10365 & 11.01 & & & & & & & & & & 1 \\
\hline Thymosin beta-4 & TYB4 & 5053 & 5.02 & & & & & & & & & & 1 \\
\hline Thymosin beta-10 & TYB10 & 4805 & 6.18 & & & & & & & & & & $\overline{1}$ \\
\hline
\end{tabular}




\section{ARTICLE}

The negatively charged PVA-SPION is the only particle type, which nearly adsorbs no proteins or surprisingly mostly those high abundant proteins showing an isoelectric point (IEP) $<7$ and therefore net negatively charge under physiological conditions, e.g. the $\mathrm{pH}$ present in $100 \%$ serum. These findings are consistent with previous reports that found that the protein corona of negatively charged silica NPs were preferentially composed of negatively charged proteins with IEP $<7 .{ }^{65}$ Interestingly, the low protein adsorption onto negatively charged PVA-SPION is supported by a greater colloidal stability and formation of smaller aggregates than for other PVA-SPION in FBS supplemented cell culture medium ${ }^{34}$. The low fouling of PVA-COOH coated SPION suggest an enhanced stability of the PVA polymer layer, indeed mediated by carboxylate-iron coordination in addition to multiple electrostatic and hydrogen bonding interactions with iron oxide surface. The exchange of the PVA dispersant by proteins might therefore be reduced and the SPION core less accessible for protein binding. The decrease in total protein adsorption for carboxylated-PVA was also demonstrated for PVA membranes exposed to human plasma as a result of negative surface potentials and anionic substitution on $\mathrm{PVA}^{57}$.

Given that many abundant proteins bind to all different PVASPION independently of the surface charges and that protein corona of the negatively charged particles did not correlate with protein charge either, electrostatic interactions is likely not the only effect to modulate the protein adsorption on PVA-SPION. Difference in protein corona composition might also be induced by variation of the effective size of the particle (hydrodynamic diameter), such it was not possible to effectively decouple in our study the net surface charge effect from other a size variation $^{50,66}$. To date, very few surfaces were found resistant to protein adsorption onto nanoparticles exposed to full serum, since the polymer surface density but also the conformation might additionally influence the pattern of adsorbed proteins $s^{67,68}$. The adsorption patterns will therefore result of a combination of physico-chemical properties, in this case, the charge, size but also the functional groups, molecular structures and polymer conformation on SPION surface.

EFFECT OF DIFFERENT SURFACE CHARGE OF INORGANIC AND METALLIC COATED SPION ON PROTEIN ADSORPTION. Here we investigated the adsorption of proteins on SPION core-solid shell nanoparticles, i.e. silica, titanium dioxide and gold with special focus of the surface charge and functionalities effect, e.g. amino on the total amount of adsorbed proteins. Metal oxide nanoparticles were also selected as model system as they are widely used for life science applications and exposed to general public in many commercial applications. Numerous high to medium abundant serum proteins were absorbed to the oxide and metal nanoparticles.

There were $40,19,53$ and 50 proteins bound on $\mathrm{SiO}_{2 \text { (APTES)- }}$

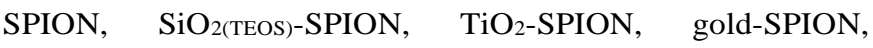
respectively. For $\mathrm{SiO}_{2}$ coated NPs, as observed in PVA-SPION, proteins preferentially bound on positively charged silica coated nanoparticles rather than the negatively charged NPs indicated the influence on surface charge of $\mathrm{SiO}_{2}$ on protein adsorption. Alpha-2-HS-glycoprotein, apolipoprotein A-I, complement 3 , fibrinogen alpha chain, cytoplasmic actin $1 \& 2$, apolipoprotein E, hemoglobin subunit alpha, complement factor B were proteins that found on all investigated inorganic and metallic nanoparticles. The presence of kininogen-2 on

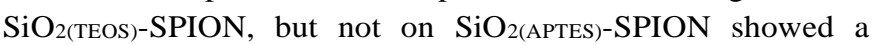
surface charge specific binding of this protein on silica surface. Kininogen-2 is an inhibitors of thiol proteases which plays an important role in blood coagulation; inhibits the thrombin- and plasmin-induced aggregation of thrombocytes ${ }^{69}$. Protein adsorption on silica NPs studied by Monopoli et al. showed some same proteins as in our work such as alpha-2-SHglycoprotein, apolipoptrotein E, apolipoptroteinAI, kininogen1 , thrombospondin- $1^{70}$. In Monopoli`s work, serum albumin was observed on the particles after 3 times washing with PBS. It could be interpreted that serum albumin is not a loosely bound protein. While in our work, serum albumin was eluted out after washing with high ionic strength solutions. This indicated that serum albumin is neither a loosely bound protein nor tightly bound protein; however, it is an intermediate.

Interestingly, $\mathrm{TiO}_{2}$ coated and gold coated NPs which also have highly negative charges showed binding of 53 and 50 proteins, respectively. The high numbers of proteins observed on both positive and highly negative charged particles indicated a requirement of sufficient surface charge for protein adsorption. In addition, protein adsorption markedly depends on the surface materials. Qualitatively, high and low abundant adsorbed serum proteins were mostly common to all negatively and positively charged surfaces. However a lower number of proteins were common to pair of surfaces (Table 4) and few low abundant proteins were found on only one material surface (Table 5) suggesting that the different particle surfaces, bare metal and metal oxide, bound proteins in a more specific manner and not simply in proportion of their abundance in the serum. Although most studies investigated the adsorption of single proteins on nanoparticle surfaces, it was shown that the protein amount adsorbed at physiological $\mathrm{pH}$ correlated well with the zetapotentials and IEPs of surfaces ${ }^{71}$. For $\mathrm{Si}, \mathrm{Ti}$ and Fe oxide NPs, the oint of zero charge are in the order of $\mathrm{SiO}_{2}(\mathrm{pH} \sim 2)<\mathrm{TiO}_{2}$ $(\mathrm{pH} \sim 5)<\mathrm{Fe}_{2} \mathrm{O} 3 \quad(\mathrm{pH} \sim 7)$ reflecting also the order of acid strength of the hydroxylated surfaces, e.g. at physiological $\mathrm{pH}$ 
silica and titanium dioxide are negatively charged while maghemite is positively charged (Table 1). However, in a complex composition of FBS, adsorption ability of each inorganic particle does not correlate to the IEP and decreases in and order of $\mathrm{TiO}_{2}>\mathrm{Fe}_{2} \mathrm{O}_{3}>\mathrm{SiO}_{2}$. This was also confirmed by work of Horie et al. ${ }^{72}$ The difference of protein adsorption results from FBS and one protein system might be explained by the influence of protein-protein interaction and others biomolecule interference such as lipid on protein-nanoparticle complex formation.

Tedja et al., reported the influence of serum protein adsorption on $\mathrm{TiO}_{2}$ increasing nanoparticle stability and cellular uptake by A549 cells. $\mathrm{TiO}_{2}$ was found to be taken up inside the cell by endocytosis mechanism ${ }^{73}$. Although in our work, the crystalline type of $\mathrm{TiO}_{2}$ was not studied. The $\mathrm{TiO}_{2}$ surface area has been reported to play a more important role than crystalinity ${ }^{72}$. Gold NPs directly interact with lipid membranes, enhancing internalization of the particles ${ }^{74}$ revealed the possibility of gold NPs binding on the lipid related compartment. Gold NPs also able to induce a protein conformational changes ${ }^{75}$. A high number of proteins bound on gold coated NPs can be also explained by preference binding of $-\mathrm{SH}$ group of proteins on the gold NPs.

Based on the presented own results and in the recent publication from Giri $^{29}$ it seems that the surface charge of the particles and of the proteins could play an important role for the formation of the protein corona. Because the surface charge of proteins is inhomogeneously distributed over the surface of the protein, we have chosen the isoelectric point (IEP) as a characteristic parameter to investigate the interaction in detail. The difference between the IEP value for a protein and the $\mathrm{pH}$ of the media determines the charge (positive if IEP $<\mathrm{pH}$, negative if IEP $>\mathrm{pH}$ ) but is also in a first estimation proportional to the difference of charges. The same is valid for the IEP of the nanoparticles. If the case of opposed charges of proteins and NP we expect attraction as vice versa of NP's and proteins with the same singe of charge. Therefore we propose an electrostatic interaction index (ESII) which is defined as following:

$E S I I=\left(I E P_{\text {Protein }}-p H_{\text {media }}\right) \cdot\left(I E P_{\text {Nanoparticle }}-p H_{\text {media }}\right)$

ESII is positive in the case both differences are negative or positive, meaning the particles have the same sign of charge (positive or negative); ESII is negative if we have a positive and negative difference. In the first case we can expect repulsion between protein and NP in the second case attraction (this is in analog to the colloidal chemistry where attraction has a negative and repulsion a positive potential). In the supplement, the ESII for all investigated particles are given, taking 7.4 as the $\mathrm{pH}$ in the media and the molecular weight of the proteins as further parameter. The calculation ESII allows in a further step to determine in which degree the adsorbtion of proteins is driven by the electrostatic interaction. When the percentage of adsorbed proteins with a negative and positive ESII per particle type taking all detected proteins was represented as $100 \%$, it is evident that with increasing IEP the amount of proteins adsorbed is increasing (Figure S1). At low IEP (COOH coated particles), PVA coated and naked SPION (all with a IEP $<7.4$, a unspecific adsorption is adsorbed, meaning the electrostatic interaction is not significant important. If the IEP > 7.4 and/or the particles are functionalized with amino groups, the electrostatic interaction is predominant and the amount of adsorbed proteins is increasing. Interestingly, a very similar behavior could be observed with particles with inorganic coating. Negatively charged particles (IEP < 7.4) have a low number of adsorbed proteins and the IEP is not relevant, whereas particles with IEP near to the $\mathrm{pH}$ of the media show increased adsorption of proteins but indifferent regarding the ESII and finally the particles with $\mathrm{NH}_{2}$ groups at the surface attract clearly proteins with a negative charge (IEP $<7.4$ and negative ESII.

\section{Experimental}

Materials section is detailed in ESI.

\section{Methods}

POLYVINYL ALCOHOL COATED SPION. SPION was produce by alkaline co-precipitation as described in previous works ${ }^{76},{ }^{77}$.

In order to obtain highly positively, positively, neutral and negatively charged PVA coated SPION, the different polymer solutions (i.e. $0.2 \% \mathrm{w} / \mathrm{v}$ M12, a mixture of Mowiol@3-85 and M12 at a mass ratio of $45,10 \% \mathrm{w} / \mathrm{v}$ Mowiol@3-85 and $6 \% \mathrm{w} / \mathrm{v}$ KL-506 solutions: see ESI) were mixed with $10 \mathrm{mgFe} / \mathrm{ml}$ SPION suspension at the $\mathrm{v} / \mathrm{v}$ ratio of 1 . The particle suspensions were stored at least one week and kept at $4^{\circ} \mathrm{C}$ until further use. The particle suspension was adjusted to $\mathrm{pH} 7.4$ by $1 \mathrm{M} \mathrm{NaOH}$ at least one day before used.

TEOS SILICA AND APTES-TEOS SILICA COATED SPION. Silica coated NPs were prepared according to Stöber sol-gel process $^{78}$ (see ESI). The obtained particles ( $\mathrm{SiO}_{2}$ (TEOS)SPION) were washed twice and dispersed in DI water (final concentration appx. $\left.0.1 \mathrm{mg}_{\mathrm{Fe}} / \mathrm{ml}\right)$.

the silica particles were functionalized with amines to produce positive charge silica coated SPION (see ESI). The obtained particles ( $\mathrm{SiO}_{2}$ (APTES)-SPION) were washed twice and dispersed in DI water (final concentration appx. $0.1 \mathrm{mg}_{\mathrm{Fe}} / \mathrm{ml}$ ). The nanoparticles were stored at $4{ }^{\circ} \mathrm{C}$.

TIO 2 COATED SPION. $\mathrm{SiO}_{2}$ (TEOS)-SPION were produced as mentioned before ${ }^{79}$. One $\mathrm{ml}$ of $\mathrm{SiO}_{2}$ (TEOS)-SPION was added into a $50 \mathrm{ml}$ ethanol solution. Titanium (IV) tetraethoxide (TEOT) as calculated to obtain $5 \mathrm{~nm} \mathrm{TiO}_{2}$ shell thickness was then added into a nanoparticle suspension. The reaction was allowed at room temperature for $3 \mathrm{~h}$. The obtained nanoparticles were then centrifuged at $30000 \mathrm{~g}$ for $45 \mathrm{~min}$. The pellet was washed 3 times with absolute ethanol before resuspended in DI water and kept at $4{ }^{\circ} \mathrm{C}$.

GOLD COATED SPION. Because it is difficult to precipitate a homogeneous gold layer on SPION, an indirect method was used. Inspired by the work of Rasch et al. ${ }^{80}$ gold nanoparticles were deposited as seeds on the positively charged amino silica coated SPION ( $\mathrm{SiO}_{2}$ (APTES)-SPION) and growing the seeds by adding additionally Au precursor. 
Particle Characterization by Photon Correlation SPECTROSCOPY (PCS). Particle sizes weighted in number were measured by dynamic laser scattering measurements carried out at $90^{\circ}$ by ZetaPALS (Brookhaven instruments corporation, USA) equipped with a BI-9000AT digital autocorrelator. The CONTIN method was used for data processing. Nanoparticles were suspended in distilled water at $100 \mu \mathrm{g}_{\mathrm{Fe}} / \mathrm{ml}$ and sonicated for few seconds. The theoretical refractive index of magnetite $(2.42)^{7}$ was used to calculate the number-weighted distribution from the raw intensity-weighted data. Viscosity, refractive index and dielectric constant of DI water were used as characteristic of the solvent.

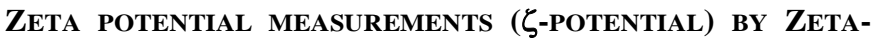
PALS. Zeta potential measurements were performed by using phase analysis light scattering with the same instrument equipped with a platinum electrode. $\zeta$-potentials were calculated from electrophoretic mobility by using theoretical models (Smoluchowski method) in ZetaPALS software packages (Brookhaven Instruments Corporation, USA) for data processing. Nanoparticles were diluted to 100 microgram of $\mathrm{Fe} / \mathrm{ml}$ in DI water.

Size MEASUREMENT BY TRANSMission ELECTRON MICROSCOPE (TEM). The size and morphology of naked SPION, silica-, gold- and $\mathrm{TiO}_{2}$ coated SPIONs were performed by using a transmission electron microscope at $120 \mathrm{kV}$ accelerating voltage (Philips/FEI CM12). Nanoparticles suspensions were diluted in DI water, and then sonicated for few seconds. The diluted nanoparticle suspensions were dropped onto carbon-coated copper grids and were allowed to dry at room temperature. TEM pictures were analyzed by image analysis software (ImageJ). The nanoparticles mean diameter and the thickness of the shell of more than a hundred particles were measured.

INCUBATION OF NANOPARTICLES WITH FBS. Different surface types of nanoparticles were incubated in the same batch of fetal bovine serum at a constant serum volume to particle surface ratio of $2.8 \mathrm{ml} / \mathrm{m}^{2}$ as previously reported by Dawson's group in similar studies of protein corona from human serum proteins adsorption on nanoparticles ${ }^{50}$. The serum proteins are in excess to the particle surface to more likely reflect a true biological situation in body fluids ${ }^{32}$. To reduce the interference of dilution effect on protein adsorption, all serum-NP incubation fractions were adjusted to the same final volume (77.8\% serum). Particle suspensions were incubated for $1 \mathrm{~h}$ at $37 \mathrm{oC}$.

Protein SeParation by a MAgnetic FiXed bed REACTOR. After incubation with FBS serum the NPs were loaded into a column in a magnetic reactor. In order to elute the proteins adsorbed on the surface of the NPs, the NPs trapped on a Ni-Fe wire were washed sequentially with buffers at increased ionic strengths i.e. phosphate buffer saline (PBS) and supplemented with a high salt gradient from $0.5-2.0 \mathrm{M} \mathrm{NaCl}$, at the flow rate of $0.5 \mathrm{ml} / \mathrm{min}$. During each washing step, trapped nanoparticleprotein complexes were equilibrated with each elution solution for $5 \mathrm{~min}$ before the elution fractions were collected. Finally, the column with $\mathrm{Ni}-\mathrm{Fe}$ wire was removed from the magnetic field of the reactor and the trapped NPs were collected in 1000 $\mu \mathrm{l}$ of last elution buffer. The collected fractions are as follows: flow through, PBS1, PBS2, PBS(0.5M NaCl), PBS(1.0M $\mathrm{NaCl}), \operatorname{PBS}(2.0 \mathrm{M} \mathrm{NaCl})$ and eluted NPs. All collection fraction volume was 1 column volume $(400 \mu \mathrm{l})$ except for the last NP fraction $(1000 \mu \mathrm{l})$. Tightly bound proteins on the NP fraction were then identified by MS analysis.

SEMI-QUANTITATIVE ANALYSIS OF PROTEINS ASSOCIATED WITH NANOPARTICLES BY NLC-MS/MSM. Proteins associated with NPs were analysed following a method detailed in ESI and in previous works ${ }^{81,82}$ in order to obtain a normalized Spectral count (SpC) amounts of each protein, identified in the LCMS/MS study of smooth and jagged surfaces, were calculated by applying the following equation:

$\mathrm{NpSpC}_{k}=\left(\frac{\left(\mathrm{SpC} / M_{\mathrm{w}}\right)_{k}}{\sum_{i=1}^{n}\left(\mathrm{SpC} / M_{\mathrm{w}}\right)_{i}}\right) \times 100$

where $\mathrm{NpSpCk}$ is the normalized percentage of spectral count for protein $\mathrm{k}, \mathrm{SpC}$ is the spectral count identified, and $\mathrm{Mw}$ is the molecular weight (in $\mathrm{kDa}$ ) of the protein $\mathrm{k}$. The MS analysis including with $\mathrm{NpSpCk}$ of tightly bound protein eluted from each type nanoparticle was represented in the supportive information (Table S1 to S9).

\section{Conclusions}

This study provides important information about SPION with different nanomaterial coating and their link with the protein composition of corona derived from a biological fluid (i.e. serum). Also, our results shed more light on the application of SPION with a specific surface meant for the binding of a specific cluster of proteins (in vitro and in vivo) in Nanomedicine and Nano-biology. The results presented in this work indicated that the composition of the protein corona is very difficult to predict. Highly abundant serum proteins are not always the most abundant proteins in the nanoparticle-protein corona. Some highly abundant serum proteins are even missing in the tightly bound protein corona. Also the charge of the particles is not the only decisive factor. It is likely to be a combination of surface chemistry and charge, which determines protein adsorption. One of the reasons for the absence of correlation between the net charge of adsorbed proteins and the surface charge of the nanoparticles is the complexity of protein nature such as protein conformation, charge distribution and hydrophobicity/hydrophilicity grade of the protein. We showed clearly that nanoparticle-protein binding strongly depends on the exact surface chemistry of the nanoparticles more than abundant level of protein in biological system. The surface charges, especially on polymeric coated SPION, play a dominant role on protein adsorption. The importance of the material can clearly see by comparing polymeric to inorganic and metallic coatings. To quantify this observe relationship between the charge of the proteins and of the nanoparticles at a given $\mathrm{pH}$ of the media, an electrostatic interaction index was introduced and applied with success to the investigated particles. The results presented in this work indicated that the 
corona composition could be generated for specific biomedical engineering, using NPs with specific surface properties. Moreover understanding of nanoparticle-protein adsorption could finally lead to the prediction of nanoparticle behavior in vitro.

\section{Acknowledgements}

This work has been supported by the NanoDiaRA project; grant agreement number 228929, funded by the EC Seventh Framework Programme FP7-NMP-2008-L, and the Swiss National Science Foundation (SNSF) fund number 205321120161/1.

\section{Notes and references}

${ }^{a}$ Laboratory of Powder Technology, Ecole Polytechnique Fédérale de Lausanne, Lausanne, Switzerland

$b$ Department of Nanotechnology, Faculty of Pharmacy, Tehran University of Medical Sciences, Tehran, Iran

c Nanotechnology Research Center, Faculty of Pharmacy, Tehran University of Medical Sciences, Tehran, Iran.

${ }^{d}$ Mat Search Consulting Hofmann, Ch. Jean Pavillard 14, 1009 Pully, Switzerland

e Department for Experimental and Molecular Medicine, Academic Medical Center, University of Amsterdam, Am-sterdam, The Netherlands *Corresponding author: heinrich.hofmann@epfl.ch

$\dagger$ Footnotes should appear here. These might include comments relevant to but not central to the matter under discussion, limited experimental and spectral data, and crystallographic data.

Electronic Supplementary Information (ESI) available: [details of any supplementary information available should be included here]. See DOI: $10.1039 / \mathrm{b} 000000 \mathrm{x} /$

1. J. H. Clement, M. Schwalbe, N. Buske, K. Wagner, M. Schnabelrauch, P. Görnert, K. O. Kliche, K. Pachmann, W. Weitschies, and K. Höffken, J. Cancer Res. Clin. Oncol., 2006, 132, 287-292.

2. A. Ito, K. Tanaka, K. Kondo, M. Shinkai, H. Honda, K. Matsumoto, T. Saida, and T. Kobayashi, Cancer Sci., 2003, 94, 308-313.

3. C. Alexiou, R. Jurgons, R. J. Schmid, C. Bergemann, J. Henke, W. Erhardt, E. Huenges, and F. Parak, J. Drug Target., 2003, 11, 139149.

4. D. Artemov, J. Cell. Biochem., 2003, 90, 518-524.

5. C. Corot, P. Robert, J.-M. Idée, and M. Port, Adv. Drug Deliv. Rev., 2006, 58, 1471-1504.

6. P. Tartaj, M. P. Morales, S. Veintemillas-Verdaguer, T. GonzálezCarreno, and C. J. Serna, J. Phys. Appl. Phys., 2003, 36, R182.

7. R. M. Cornell and U. Schwertmann, The Iron Oxides: Structure, Properties, Reactions, Occurrences and Uses, John Wiley \& Sons, 2006.

8. S. Laurent, D. Forge, M. Port, A. Roch, C. Robic, L. Vander Elst, and R. N. Muller, Chem. Rev., 2008, 108, 2064-2110.

9. C. Chouly, D. Pouliquen, I. Lucet, J. J. Jeune, and P. Jallet, J. Microencapsul., 1996, 13, 245-255.

10. S. Saito, M. Tsugeno, D. Koto, Y. Mori, Y. Yoshioka, S. Nohara, and K. Murase, Int. J. Nanomedicine, 2012, 7, 5415-5421.

11. F. M. Kievit, O. Veiseh, N. Bhattarai, C. Fang, J. W. Gunn, D. Lee, R. G. Ellenbogen, J. M. Olson, and M. Zhang, Adv. Funct. Mater., 2009, 19, 2244-2251.

12. M. Mahmoudi, A. Simchi, M. Imani, and U. O. Häfeli, J. Phys. Chem. C, 2009, 113, 8124-8131.

13. Challa S. S. R. Kumar, Magnetic nanomaterials, Wiley-VCH, Weinheim, Edited by Challa Kumar., 2009.

14. K. T. Thanh Nguyen, Magnetic nanoparticles: from fabrication to clinical applications: theory to therapy, chemistry to clinic, bench to bedside, CRC Press, Taylor and Francis Group, LLC, Boca Raton, FL, Theory Ed., 2012.

15. R. Landsiedel, L. Ma-Hock, A. Kroll, D. Hahn, J. Schnekenburger, K. Wiench, and W. Wohlleben, Adv. Mater., 2010, 22, 2601-2627.

16. I. Lynch, T. Cedervall, M. Lundqvist, C. Cabaleiro-Lago, S. Linse, and K. A. Dawson, Adv. Colloid Interface Sci., 2007, 134-135, $167-$ 174.

17. A. E. Nel, L. Mädler, D. Velegol, T. Xia, E. M. V. Hoek, P. Somasundaran, F. Klaessig, V. Castranova, and M. Thompson, Nat. Mater., 2009, 8, 543-557.

18. E. Amstad, M. Textor, and E. Reimhult, Nanoscale, 2011, 3, 28192843.

19. Gref, Lück, Quellec, Marchand, Dellacherie, Harnisch, Blunk, and Müller, Colloids Surf. B Biointerfaces, 2000, 18, 301-313.

20. T. Cedervall, I. Lynch, M. Foy, T. Berggård, S. C. Donnelly, G. Cagney, S. Linse, and K. A. Dawson, Angew. Chem. Int. Ed Engl., 2007, 46, 5754-5756.

21. C. Salvador-Morales, E. Flahaut, E. Sim, J. Sloan, M. L. H. Green, and R. B. Sim, Mol. Immunol., 2006, 43, 193-201.

22. K. Thode, M. Lück, W. Semmler, R. H. Müller, and M. Kresse, Pharm. Res., 1997, 14, 905-910.

23. N. L. Anderson and N. G. Anderson, Mol. Cell. Proteomics MCP, $2002,1,845-867$.

24. S. Lista, F. Faltraco, and H. Hampel, Prog. Neurobiol., 2013, 101102, 18-34.

25. Y. Shen, J. Kim, E. F. Strittmatter, J. M. Jacobs, D. G. Camp 2nd, R. Fang, N. Tolié, R. J. Moore, and R. D. Smith, Proteomics, 2005, 5, 4034-4045.

26. V. Mirshafiee, M. Mahmoudi, K. Lou, J. Cheng, and M. L. Kraft, Chem. Commun., 2013, 49, 2557-2559.

27. S. Krol, R. Macrez, F. Docagne, G. Defer, S. Laurent, M. Rahman, M. J. Hajipour, P. G. Kehoe, and M. Mahmoudi, Chem. Rev., 2013, 113, 1877-1903.

28. A. Elsaesser and C. V. Howard, Adv. Drug Deliv. Rev., 2012, 64, 129-137.

29. K. Giri, K. Shameer, M. T. Zimmermann, S. Saha, P. K. Chakraborty, A. Sharma, R. R. Arvizo, B. J. Madden, D. J. Mccormick, J.-P. A. Kocher, R. Bhattacharya, and P. Mukherjee, Bioconjug. Chem., 2014.

30. C. C. Fleischer and C. K. Payne, J. Phys. Chem. B, 2014.

31. T. Cedervall, I. Lynch, S. Lindman, T. Berggård, E. Thulin, H. Nilsson, K. A. Dawson, and S. Linse, Proc. Natl. Acad. Sci., 2007, 104, 2050-2055.

32. J. Klein, Proc. Natl. Acad. Sci. U. S. A., 2007, 104, 2029-2030.

33. B. Steitz, J. Salaklang, A. Finka, C. O’Neil, H. Hofmann, and A. Petri-Fink, Bioconjug. Chem., 2007, 18, 1684-1690.

34. V. Hirsch, C. Kinnear, M. Moniatte, B. Rothen-Rutishauser, M. J. D. Clift, and A. Fink, Nanoscale, 2013, 5, 3723-3732.

35. A. Salvati, A. S. Pitek, M. P. Monopoli, K. Prapainop, F. B. Bombelli, D. R. Hristov, P. M. Kelly, C. Åberg, E. Mahon, and K. A. Dawson, Nat. Nanotechnol., 2013, 8, 137-143.

36. H. T. R. Wiogo, M. Lim, V. Bulmus, J. Yun, and R. Amal, Langmuir, 2011, 27, 843-850.

37. C.-C. You, A. Chompoosor, and V. M. Rotello, Nano Today, 2007, 2, 34-43.

38. M. P. Monopoli, C. Åberg, A. Salvati, and K. A. Dawson, Nat. Nanotechnol., 2012, 7, 779-786.

39. R. R. Arvizo, K. Giri, D. Moyano, O. R. Miranda, B. Madden, D. J. McCormick, R. Bhattacharya, V. M. Rotello, J.-P. Kocher, and P. Mukherjee, PLoS ONE, 2012, 7.

40. K. Suttiponparnit, J. Jiang, M. Sahu, S. Suvachittanont, T. Charinpanitkul, and P. Biswas, Nanoscale Res. Lett., 2010, 6, 27.

41. C. Schulze, C. Schulze, A. Kroll, C. Schulze, A. Kroll, C.-M. Lehr, U. F. Schäfer, K. Becker, J. Schnekenburger, C. Schulze Isfort, R. Landsiedel, and W. Wohlleben, Nanotoxicology, 2008, 2, 51-61.

42. F. Rezaee, B. Casetta, J. H. M. Levels, D. Speijer, and J. C. M. Meijers, PROTEOMICS, 2006, 6, 721-730.

43. K. C. S. Queiroz, R. A. Tio, C. J. Zeebregts, M. F. Bijlsma, F. Zijlstra, B. Badlou, M. de Vries, C. V. Ferreira, C. A. Spek, M. P. Peppelenbosch, and F. Rezaee, J. Proteome Res., 2010, 9, 60526059.

44. S. Ray, P. J. Reddy, S. Choudhary, D. Raghu, and S. Srivastava, J. Proteomics, 2011, 74, 2660-2681. 
45. X. Zheng, H. Baker, W. S. Hancock, F. Fawaz, M. McCaman, and E. Pungor Jr, Biotechnol. Prog., 2006, 22, 1294-1300.

46. D. Simberg, J.-H. Park, P. P. Karmali, W.-M. Zhang, S. Merkulov, K. McCrae, S. N. Bhatia, M. Sailor, and E. Ruoslahti, Biomaterials, 2009, 30, 3926-3933.

47. M. Rankl, T. Ruckstuhl, M. Rabe, G. R. J. Artus, A. Walser, and S. Seeger, ChemPhysChem, 2006, 7, 837-846.

48. A. A. Vertegel, R. W. Siegel, and J. S. Dordick, Langmuir, 2004, 20 , $6800-6807$.

49. W. Shang, J. H. Nuffer, J. S. Dordick, and R. W. Siegel, Nano Lett., 2007, 7, 1991-1995.

50. M. Lundqvist, J. Stigler, G. Elia, I. Lynch, T. Cedervall, and K. A. Dawson, Proc. Natl. Acad. Sci., 2008, 105, 14265-14270.

51. M. Rabe, D. Verdes, and S. Seeger, Adv. Colloid Interface Sci., 2011, 162, 87-106.

52. P. Vilaseca, K. A. Dawson, and G. Franzese, Understanding surfaceadsorption of proteins: the Vroman effect, 2012.

53. D. Dell'Orco, M. Lundqvist, C. Oslakovic, T. Cedervall, and S. Linse, PLOS ONE, 2010, 5, e10949.

54. M. Lundqvist, J. Stigler, T. Cedervall, T. Berggård, M. B. Flanagan, I. Lynch, G. Elia, and K. Dawson, ACS Nano, 2011, 5, 7503-7509.

55. H. Zhang, K. E. Burnum, M. L. Luna, B. O. Petritis, J.-S. Kim, W.-J. Qian, R. J. Moore, A. Heredia-Langner, B.-J. M. Webb-Robertson, B. D. Thrall, D. G. Camp, R. D. Smith, J. G. Pounds, and T. Liu, PROTEOMICS, 2011, 11, 4569-4577.

56. A. Gessner, R. Waicz, A. Lieske, B. Paulke, K. Mäder, and R. H. Müller, Int. J. Pharm., 2000, 196, 245-249.

57. K. E. Ryu, H. Rhim, C. W. Park, H. J. Chun, S. H. Hong, J. J. Kim, and Y. M. Lee, Macromol. Res., 2003, 11, 451-457.

58. D. A. Barrett, M. S. Hartshome, M. A. Hussain, P. N. Shaw, and M. C. Davies, Anal. Chem., 2001, 73, 5232-5239.

59. K. Ogawara, K. Furumoto, S. Nagayama, K. Minato, K. Higaki, T. Kai, and T. Kimura, J. Controlled Release, 2004, 100, 451-455.

60. G. Döring, Pediatr. Pulmonol., 1999, 28, 363-375.

61. W. Jahnen-Dechent, C. Schäfer, M. Ketteler, and M. D. McKee, J. Mol. Med., 2008, 86, 379-389.

62. E. Hellstrand, I. Lynch, A. Andersson, T. Drakenberg, B. Dahlbäck, K. A. Dawson, S. Linse, and T. Cedervall, FEBS J., 2009, 276, 3372 3381.

63. R. Cukalevski, M. Lundqvist, C. Oslakovic, B. Dahlbäck, S. Linse, and T. Cedervall, Langmuir, 2011, 27, 14360-14369.

64. G. Gunkel and W. T. S. Huck, J. Am. Chem. Soc., 2013, 135, 70477052 .

65. S. Tenzer, D. Docter, S. Rosfa, A. Wlodarski, J. Kuharev, A. Rekik, S. K. Knauer, C. Bantz, T. Nawroth, C. Bier, J. Sirirattanapan, W. Mann, L. Treuel, R. Zellner, M. Maskos, H. Schild, and R. H. Stauber, ACS Nano, 2011, 5, 7155-7167.

66. D. Hühn, K. Kantner, C. Geidel, S. Brandholt, I. De Cock, S. J. H. Soenen, P. Rivera_Gil, J.-M. Montenegro, K. Braeckmans, K. Müllen, G. U. Nienhaus, M. Klapper, and W. J. Parak, ACS Nano, 2013, 7, 3253-3263.

67. C. D. Walkey, J. B. Olsen, H. Guo, A. Emili, and W. C. W. Chan, J. Am. Chem. Soc., 2012, 134, 2139-2147.

68. C. Sacchetti, K. Motamedchaboki, A. Magrini, G. Palmieri, M. Mattei, S. Bernardini, N. Rosato, N. Bottini, and M. Bottini, ACS Nano, 2013, 7, 1974-1989.

69. N. Kitamura, Y. Takagaki, S. Furuto, T. Tanaka, H. Nawa, and S. Nakanishi, Nature, 1983, 305, 545-549.

70. M. P. Monopoli, D. Walczyk, A. Campbell, G. Elia, I. Lynch, F. Baldelli Bombelli, and K. A. Dawson, J. Am. Chem. Soc., 2011, 133, $2525-2534$

71. K. Rezwan, A. R. Studart, J. Vörös, and L. J. Gauckler, J. Phys. Chem. B, 2005, 109, 14469-14474.

72. M. Horie, K. Nishio, K. Fujita, S. Endoh, A. Miyauchi, Y. Saito, H. Iwahashi, K. Yamamoto, H. Murayama, H. Nakano, N. Nanashima, E. Niki, and Y. Yoshida, Chem. Res. Toxicol., 2009, 22, 543-553.

73. R. Tedja, M. Lim, R. Amal, and C. Marquis, ACS Nano, 2012, 6, 4083-4093.

74. J. Lin, H. Zhang, Z. Chen, and Y. Zheng, ACS Nano, 2010, 4, 54215429.

75. S. H. D. P. Lacerda, J. J. Park, C. Meuse, D. Pristinski, M. L. Becker, A. Karim, and J. F. Douglas, ACS Nano, 2010, 4, 365-379.
76. M. Chastellain, A. Petri, and H. Hofmann, J. Colloid Interface Sci., 2004, 278, 353-360.

77. A. Petri-Fink, M. Chastellain, L. Juillerat-Jeanneret, A. Ferrari, and H. Hofmann, Biomaterials, 2005, 26, 2685-2694.

78. W. Stöber, A. Fink, and E. Bohn, J. Colloid Interface Sci., 1968, 26, $62-69$.

79. U. Sakulkhu, PhD Thesis, EPFL, 2013.

80. M. R. Rasch, K. V. Sokolov, and B. A. Korgel, Langmuir, 2009, 25, $11777-11785$.

81. U. Sakulkhu, M. Mahmoudi, L. Maurizi, J. Salaklang, and H. Hofmann, Sci. Rep., 2014, 4.

82. U. Sakulkhu, L. Maurizi, M. Mahmoudi, M. M. Motazacker, M. Vries, A. Gramoun, M.-G. B. Ollivier, J.-P. Vallee, F. Rezaee, and H. Hofmann, Nanoscale, 2014. 